\title{
The Role of Governance in The Development of Universities
}

\author{
Tariq moahammed Althwaini, talthwaini@ksu.edu.sa
}

Mafugie Darboe, 442106446@student.ksu.edu.sa

Mohammed Ahmed Mosa Alshahrani, momo2288211@gmail.com

Faisal Obeid Hamoud Alharbi, faisal11@live.com

King Saud University - KSA

\begin{abstract}
In the past decade, the unemployment rate amongst graduates from higher education systems in Arab countries had consistently grown higher, this unfortunate situation is as a result of the huge margin between the skills sought by the labor market and the skills acquired by higher education graduates.

This article Identifies the significance of university governance in tackling the current challenges of these higher institutions.

The existence of an effective university governance would not just contribute to knowledge production, it would as well equip its graduates to become useful, resourceful and productive members of society.

Corporate governance has become a vital component that will allow those in charge of institutions to mobilize resources, design, implement, monitor and evaluate the efficiency and effectiveness of performance, this ensures rational, informed and transparent decision making that leads to efficiency and effectiveness at the organizational level.
\end{abstract}

This article as well delves on a great number of Arab and foreign universities that applied and benefited from the governance model at local levels.

Keywords: university, Governance, Development of Universities. 


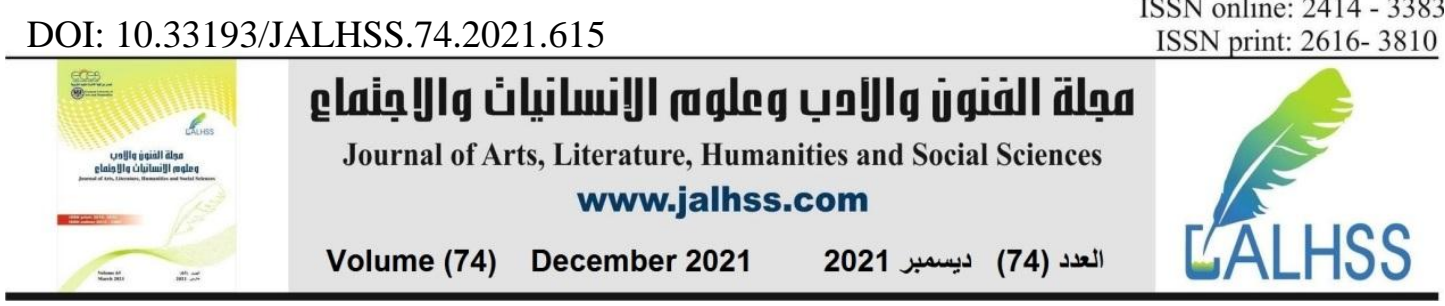

\section{Introduction}

Higher education systems in Arabian countries are under pressure due to a gap between the skills sought by labor markets and the skills acquired by higher education graduates. Unemployment rates amongst university graduates in most Arab countries have been consistently higher than in other regions during the past decade. The recent financial crisis has made this problem even more serious. Universities need to resort to innovation in order to provide an education that enables their graduates to become competitive and contribute to the economic and social growth of their countries (World Bank, 2012, p. 11) which means Higher education systems in Arab countries need a good change to face it .

Despite the emergence and use of the concept of governance at the beginning in the business sector, it quickly moved after that to many fields, including education, and governance became a criterion for determining the quality of educational institutions ((Degerstedt, 2000). Universities are one of the most important institutions to which this concept has moved, and governance has become, accordingly, a criterion against which the quality of universities is measured.

According to (Shattock, 2006) the term governance is used to describe all those structures, processes, and activities that are involved in the planning and direction of institutions and people who work in higher education. The goal of good governance is a strong organization that achieves high levels of performance and is accountable to the community it serves. It is hoped that the governance systems in educational institutions will contribute to encouraging all of its components to have a say in making improvements to the institution and advancing its mission (Tilley, 1998).

This discussion of "governance" thus encompasses analysis in the broadest terms of how higher education is governed. Governance comprises a complex web including the legislative framework, the characteristics of the institutions and how they relate to the whole system, how money is allocated to institutions and how they are accountable for the way it is spent, as well as less formal structures and relationships which steer and influence behavior (McKenzie, 2003, p.61)

Institutional governance in higher education can be divided in two types according to content: academic and general or administrative decision making (Knowles, 1978). Academic decision-making involves issues related to the questions of what should be taught, who should teach it, how it should be taught, who should be taught, how academic funds should be distributed, who and how should academically plans and policies be developed (Smyth, 1978). 


\begin{tabular}{|c|c|c|c|c|}
\hline 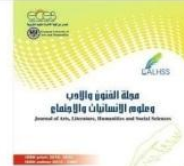 & 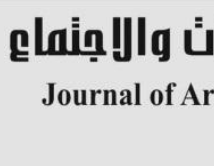 & 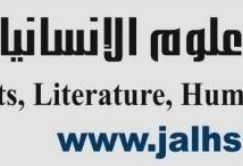 & $\begin{array}{l}\text { es and Social Sciences } \\
\text { om }\end{array}$ & \\
\hline$=$ & Volume (74) & December 2021 & العدد (74) ديسمبر 2021 & \\
\hline
\end{tabular}

Administrative decision making, on the other hand, involves general budget allocation, strategic planning, administrative and management issues in general (Knowles, 1978). Using the term "academic" more generally, Cowley (1980) speaks of academic government as the social control of academic institutions. Under his perspective academic government takes place at two levels of specificity: the policy and the operational. Finally, it is convenient to consider a historical dimension of academic governance, as the term does not have a uniform meaning throughout time ( Galaz-Fontes , 2012 , p.1)

\section{Research Problem}

Politics is a source of most public university existence. The state, on behalf of the people, creates the institutions, provides significant portions of revenue, and regulates institutional behavior. State systems of governance and coordination act as agents of the state's political authority and regulate, direct, and control universities in response to the political process. This power flows clearly and directly from public ownership of the state university, and the trustees (regents, board of education members) have an obligation to manage the institutions on behalf of the people as directed by state officials. (Lombardi, 2002, p10)

Universities are the nucleus for building an educated generation, and it is their responsibility to rehabilitate an educated generation. This generation has families and the operators in the labor market are interested in it. From all of the above, it is clear that there are many stakeholders who pay attention to the quality of the educational process, safety of the organizational environment and institutional performance. There is an active participation of stakeholders through the use of the concepts of transparency, integrity, participation, clarity, application of laws, regulations and instructions, and accountability; To develop and build societies, bring about positive changes in the countries that founded these universities, prepare generations capable of keeping pace with knowledge and technical development, and meet the needs of their societies in a way that keeps pace with the times (Corcoran and Suzanne, 2004). In view of the absence of this concept and the scarcity of studies in many universities as well as the lack of its full application, the problem of the study is determined in building a proposed theoretical framework to formulate the principles and foundations of university governance, and the study aims to identify the reality of applying the principles and foundations of governance in universities, by making sure that 


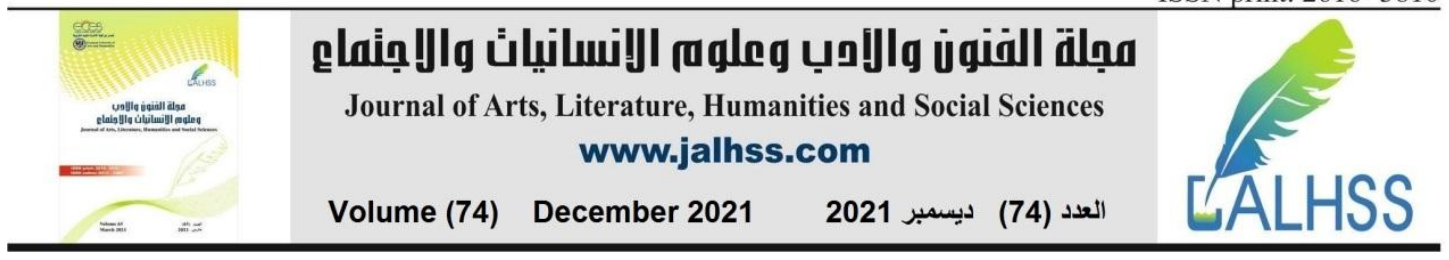

Implementing governance with all its requirements and standards, and identifying the degree to which governance is applied.

Also, the process of evaluating the performance of supervisors in universities is an important requirement of governance after the increase in the number of universities for development, modernization and correction of errors, and the importance of university governance is to achieve confidence in information related to evaluating the performance of supervisors (Geena and Muscio, 2009), and recommended (kim, 2007) to find Clear mechanisms to enable officials to regularly provide the necessary clarifications to stakeholders on how to use their powers and discharge their duties in a manner that is integrated with the process of transparency and disclosure. (Ehrenberg, 2004) indicates that the loss of oversight mechanisms, lack of transparency, weak governance rules and controls, and lack of accountability led to the abuse of power and the spread and expansion of corruption, which led to low rates of development and a low level of welfare, and that bypassing and disrespecting the law, which originally resulted due to the lack of availability Accountability and transparency tools. In light of the above and through an analysis of the theoretical framework, the need for this study emerged to reach the foundations and principles of university governance and to know the degree of application of governance in universities.

\section{Research purposes}

The research aims to achieve the following:

1- Increasing knowledge of the concept of governance in general and the governance of universities in particular.

2- Identify the concepts associated with the term university governance.

3- Identifying the role of university governance in facing the current challenges facing universities.

\section{Research questions}

1- What is the concept of corporate governance in general and the concept of university governance in particular?

2- How does the concept of university governance contribute to facing the challenges facing universities?

3- To what extent is governance applied in some universities?

4- What is the benefit of applying governance at the local level? 


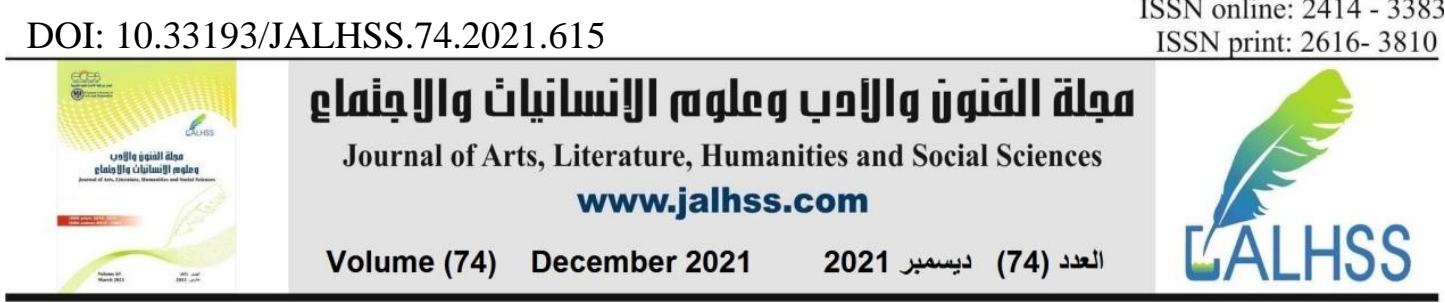

\section{Research Need}

This research derives its importance from two aspects:

Firstly, the importance of the role of universities in light of the challenges they face and the need to keep pace with reforms to ensure that education systems are managed in an effective manner.

Secondly, the increasing interest in the issue of university governance in recent years, and the fact that its foundations and mechanisms are among the modern concepts at the global level in general, and at the local level in particular. Awareness of these concepts and their applications leads to achieving a great deal of transparency and justice, and helps the university administration to play its main role in facing the challenges it faces.

\section{Methodology}

In answering the questions of the study, the researcher relied on the Analytical Descriptive Approach to the subject of the study, and this approach is applied in many research and studies, especially those dealing with social phenomena related to daily practices. Where the researcher reviewed the evidence of governance and its experiences in educational institutions, especially those issued by international, regional and local institutions. The researcher also adopted this approach in defining the research problem, which was to highlight the analytical method because it is used to study accurate descriptions of the phenomena through which great progress can be made in solving problems. And then suggest some recommendations that may contribute to giving a useful reference to the issue of university governance.

\section{The concept and importance of corporate governance in general}

The issue of governance is a relatively recent topic, but its roots go back to the year 1932. Interest in this topic has increased after the failures and stumbling blocks faced by many organizations, which increased the need for governance that includes mechanisms that ensure efficient decision-making and improve the performance of the organization. Therefore, governance has become an issue of interest to the international community, given its growing importance in ensuring the proper functioning of work, stability and quality improvement in organizations.

According to) Braun, 2009) that the term corporate governance is derived from the existence of a symmetry between the governance of states and corporate governance. 


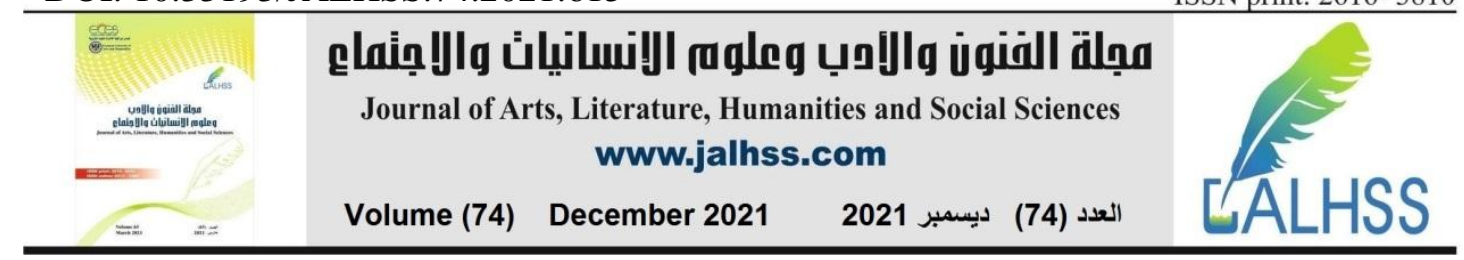

Corporate governance is now as important in the global economy as state governance (Kostyuk, Alexander N, et.al, 2007:2).

There are those who believe in the narrow concept and a broad concept of corporate governance, from a narrow perspective, corporate governance deals with the methods used by the providers of funds to the institution to secure themselves, and ensure that they receive a return on their investments (Shleifer, 1997:738).

From a broad perspective, corporate governance is seen as a system of laws, rules and factors that control the institution's operations. It includes the institution's relationship with stakeholders, society, a set of laws, instructions, listing rules, and voluntary private sector practices that enable the company to attract capital, efficiently achieve institution goals, and meet both legal obligations and the aspirations of society in general (Gregory, 2001:7).

Whatever the organization's goal is taken, effective governance ensures that the board of directors and managers are accountable for its follow-up. Effective corporate governance encourages the efficient use of resources within the organization and at the level of the economy as a whole. It also helps to ensure the institution's compliance with the laws, instructions and aspirations of society, and in monitoring managers in their use of the institution's assets to support efforts to reduce corruption.

Weak corporate governance appears to be associated with high operating costs. In addition, higher operating costs and a corresponding decrease in the level of performance of the institution translate into economic costs for countries, and therefore less attractive investments.

\section{The concept of university governance}

University governance is a key component of the recent focus on university education reform trends around the world. The concept of university governance (a relatively new concept developed by Clark in 1983 as one of the first classification methods in the world) addresses how universities and higher education systems achieve and implement their goals, and the way their institutions are managed and their achievements monitored. (World Bank, 2012: 12).

Governance does not refer much to what institutions do, but rather to how they perform it, i.e. the methods and means by which the institution determines it confronts it and organizes itself to achieve the purpose of its existence. Governance, in general, can be understood as involving the distribution of power and tasks amongst units 


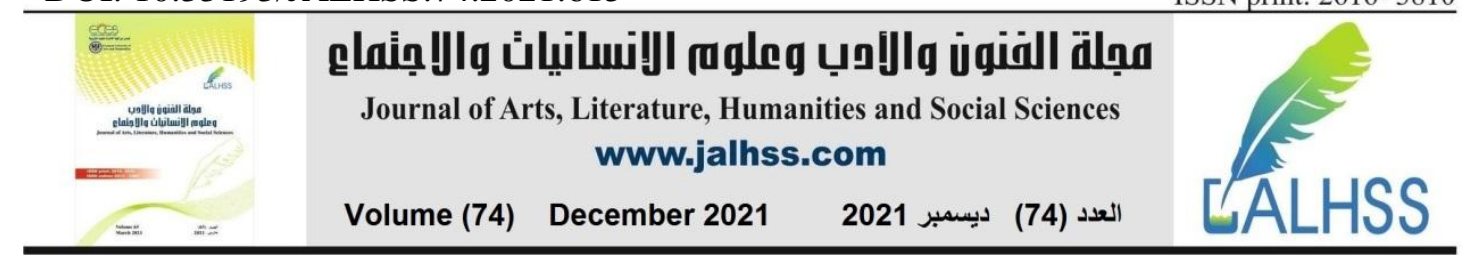

within a larger entity, the methods of communication and control amongst them, and the flow of relationships between the entity and the surrounding environment.

In higher education, governance processes address multiple dimensions of the institution: how its parts are cohesive, how they exercise authority, how they communicate with internal members (students and faculty), how they make decisions, how and to what extent they delegate responsibility for internal decisions and actions. The governance structure includes the role of boards of directors and heads of institutions, their participation structures, their procedural and disciplinary rules, their policies for resource allocation, and their arrangements for performance management, follow-up and reporting (OECD, 2010: 86).

The concept of university governance has emerged recently to express the real crisis that the university institution is going through and the proposed solutions to it, a crisis that is represented in the fact that there are university administrations placed by the executive authority above students and faculty members, to be tasked with making decisions related to their affairs, without being any of them (students, faculty members) have the right to discuss or object to these decisions. This weakens the development of the university as an academic institution in which it is supposed to reformulate the cultural, customary and scientific trends of society, given that the decision is placed in the hands of one of the parties to the university institution, and the rest of the parties from students and faculty members are in the position of the recipient of these decisions and committed to implementing them without discussion. For example, decisions related to educational curricula are taken without students having the right to participate in formulating plans for these curricula and their goal, as well as student unions as entities whose aim is to train students to participate in public life and promote democratic values and respect for others (Baskerville, 2011: 2).

\section{The role and importance of university governance}

What is concerned about universities is that higher education institutions are no longer the only major players in the production of knowledge and the dissemination of research and education as today universities are only one amongst many actors involved in the production of knowledge.

The world rankings have increased pressures for university governance. The rankings of top universities are linked to three related factors: concentration of talent, availability of funding, and governance (Salmi, 2009:19). The autonomy that allows institutions to manage their own resources competently and to respond quickly to the 


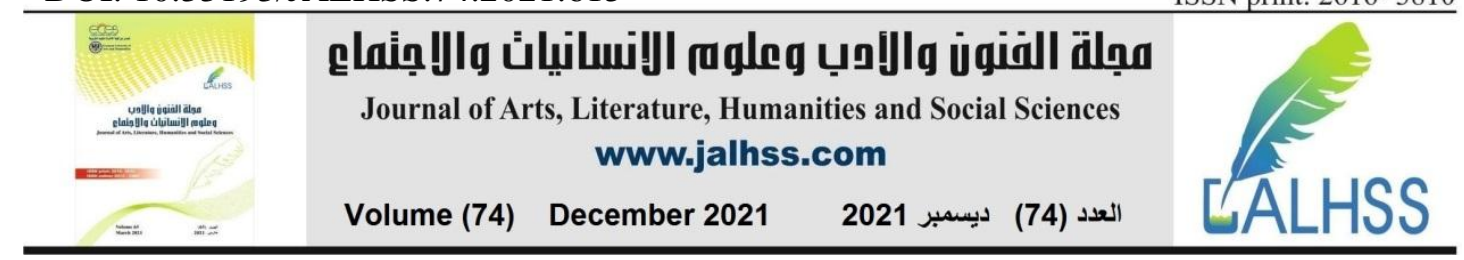

demands of a rapidly changing global market is essential, but not alone is sufficient to nominate and maintain Universities within the rankings Other critical attributes of governance are needed, such as inspirational leaders, a strong strategic vision for institutional direction, a philosophy of success and excellence, and organizational development and change (Fabric and Alexander, 2008:19).

In the face of all these challenges, university governance constitutes an important driver for bringing about change and facing challenges, as how institutions are managed is among the most decisive factors in achieving their goals. Corporate governance has become a vital component that will allow those in charge of those institutions to design, implement, monitor and evaluate the efficiency and effectiveness of performance.

Good governance facilitates rational, informed and transparent decision making, and leads to efficiency and effectiveness at the organizational level. Decision-making should ensure an appropriate balance between the various interests, recognition of the reasons behind the conflict of interests, and not giving priority to one interest over the other for arbitrary reasons.

One of the main considerations is the relationship between corporate governance and the state, primarily the extent of institutional independence and its impact on institutional performance.

The governance of universities contributes to the creation of independent institutions that have governing councils or bodies responsible for determining the strategic direction of these institutions, monitoring their financial soundness and ensuring the effectiveness of their management. In the United Kingdom, for example, all higher education institutions receive funding from public funds that constitute some percentage of their total income, but the government does not manage these funds directly but rather operates through a series of funding boards to provide institutions with financial support and public guidance. These government agencies have no direct role in determining the academic programs offered by institutions of higher education or directing academic research. The employment of workers in these institutions is carried out by the institutions themselves and not by the state, and their salaries are negotiated at the national level through a joint body representing both the administration and labor unions, which presents what they agree upon in the form of recommendations and to the participating colleges and universities (Trakman, 2011:9).

One of its most important principles is transparency, accountability, equality and active participation related to the quality of decision-making, by activating internal 


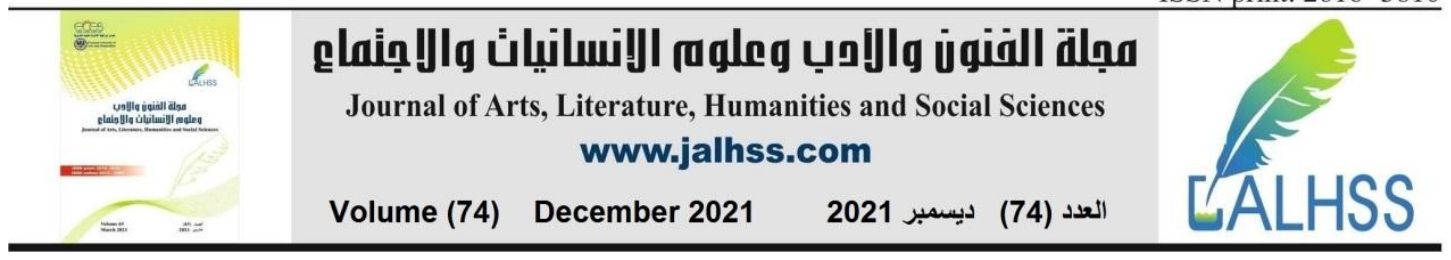

and external participation by creating a system that helps in the effective representation of all levels in the decision-making process (Fabric and Alexander, 2008:19), and those principles are in details:

The first principle: the extent to which the senior management has a clear vision.

The second principle: Balance in the distribution of responsibilities and powers amongst the governing councils.

The third principle: Participation (it is the right of everyone to participate in decisionmaking, either directly or through the selection of their representatives).

Fourth principle: Regulations and laws: (Strengthening the rule of law so that regulations and laws are just and implemented with integrity).

Fifth Principle: Transparency and Information Disclosure Policy: (Identity in the design of systems, mechanisms, legislation and other tools with their applications, which guarantee the right of each party to the university and the ease of information flow and access to it).

Sixth Principle: Accountability: (Enabling relevant individuals inside and outside the university to monitor work without disrupting it, or offending others, which is the other side of leadership, and it is a commitment to accountability or answering the responsibility that is assigned to them). The seventh principle: work ethics and social responsibility.

6. Models of Arab and foreign universities that have applied governance and the extent of benefiting from its application at the local level

\section{"California university" in the USA:}

The United States is one of the first countries in the world that sought to implement governance in universities with the aim of developing and improving the administrative methods used in organizing university work, activating monitoring systems over university education, ensuring a good level of university performance, and supporting university decisions based on participation. With regard to the administration of the University of California, it is concentrated in a higher council that represents the supreme authority known as the Board of Trustees, and some of its members are chosen by the governor of the state and some are elected by members of the Council, and it includes a number of important people at the state level to which the university belongs, such as the mayor of the state and some members of the legislatures And supervisory or senior owners of money heads, businessmen and 


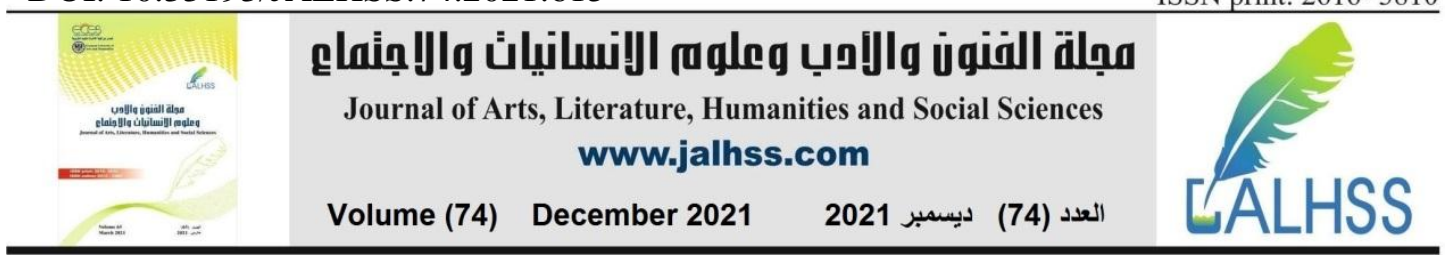

people of high social and religious status, in addition to the president of the university and current distinguished students who have graduated before and achieved great achievements (Dee, 2006). This council appoints the university's senior administrators and officials, approves the nomination of department heads, monitors the university's commitment to its vision and achieves its mission and goals, supervises the university's financial situation, follows up on the provision of the necessary financial credits and monitors its disbursement. The councils take decisions either by voting in the case of large councils or by deliberation among the members of the council in the university. The University of California implements this system of governance strictly in the university system, and this is reflected in it positively, as it has become one of the most advanced and famous universities in America and attracts many students (Lee, 2010).

\section{Cambridge University in the UK}

The experience of the United Kingdom in the governance of universities is one of the most important current experiences, as it has a declared system for applying the principles of university governance, and this has clearly contributed to the achievement of its higher education institutions in advanced positions in the world rankings of universities as is evident in the University of Cambridge (Henke, 2007). Its system contains multiple councils and committees that work to coordinate between them and other universities, and perform several tasks, including determining the percentage and number of students at each university level and in certain specializations, through which the government's contribution to the budget is determined. They are considered independent counsels that do not follow the instructions of the Ministry of Education. Most of them receive annual subsidies from public money, enjoy transparency, accountability and responsibility, and adhere to certain values. As a result of its application of the government system, this university was named the best university in Britain, where students became their goal to enter this university, which achieved great success (Chan, 2007).

\section{Al-Quds University in Palestine:}

Al-Quds University is one of the leading academic institutions in Palestine, which provides educational services to the most important segment of society, namely the youth, and seeks to achieve its goals with a high degree of efficiency and effectiveness, through human resources and qualified cadres, which consist of a selection of distinguished academics and an experienced administrative staff. They work side by side for the success of the educational process. This university involved all its administrators and students in making the decision through the implementation 


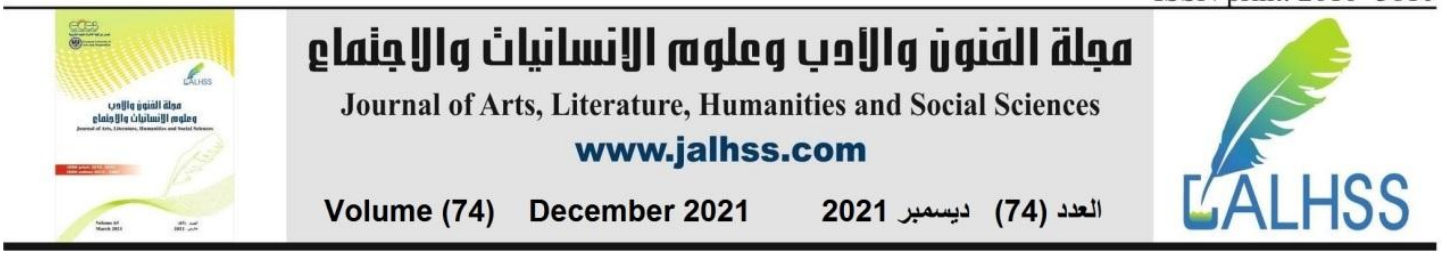

of governance. The university works to implement the system of governance among students without discrimination, and that is transparent and without resorting to ambiguity. But even with the proper application of governance, this does not work greatly to attract distinguished employees and students (Halawa and Taha, 2012).

\section{Fayoum University in Egypt:}

Fayoum University applies governance standards to a good degree, where the accountability criterion has the highest degree, followed by the criterion of social awareness, fairness, responsibility, and finally independence. Where the university's website publishes the approved decisions of the council and the results of the work, which are constantly updated. The president of the council enjoys academic and administrative independence with a high degree of governance, and the absence of any external pressures or influences affecting the decisions of the free university council, as the members of the University Council meet at least once a month. Voting is also used easily and without favor in the University Council, and the University Council is keen to achieve quality assurance of education in its affiliated colleges (Sherif, 2007).

\section{CONCLUSION}

There is great interest from the government of the Kingdom of Saudi Arabia towards the development and modernization of education, especially university education, where university education is one of the main pillars that contribute to the formation of the individual and society, and the crystallization of its epics in the present and the future together, and since universities operate in rapidly changing environments, their survival and success depends On effective responses to many forces, economic, administrative, and technology variables, and dealing with them with a flexible and advanced strategy, the countries that hold the corners of these variables have become the countries with rates of progress.

If governance is one of the modern administrative concepts that conscious administrations, including the administration of higher education in Saudi universities in general, and King Saud University in particular, must adopt it because of its importance in the events of administrative development in particular - in addition to its contribution to the development of organizations towards achieving their goals.

The eleventh objective of the general objectives of the Saudi development plan stipulated the necessity of continuing economic, social and institutional reform, and developing systems related to raising efficiency, improving performance, working to 
establish the principle of transparency and accountability, and supporting self-society institutions in developing their development activities.

As the results of the second Riyadh Forum (2005) recommended, it is necessary to issue a system of transparency and economic accountability in the Kingdom, in which several elements must be present, including: ensuring the right of the business community to obtain information, and emphasizing that the origin is the dissemination of information and data and that the publishing mechanism is not limited to The Official Gazette, but rather the modern scientific means of all kinds, including the Internet.

In spite of the foregoing, it cannot be said that the application of governance in its three well-known dimensions (accountability, transparency, and participation) is actually applied in Saudi universities, but there are some studies such as the Abu Hamid study (2007), the Al-Zahrani study (1432), the study of Abu and Karim, and Al-Thawini (2014).) The degree to which universities practice governance from the point of view of faculty members was moderately high.

The results of this study demonstrate that the top universities Through the current study and by presenting international experiences in applying governance in universities

\section{Acknowledgement}

The authors would like to thanks all those who facilitated the Recherche in king Saud university.

\section{References}

1. Baskerville et al., 2011, Handbook of Higher Education in the UK and Partnerships with Universities Abroad, UK Higher Education Europe and International Affairs Unit, Research Series.

2. Braun, D. (1999) "Changing Governance Models in Higher Education: The Case of the New Managerialism" Swiss Political Science Review, Vol. 5, No. 3, St. Gallen.

3. Chan, S., (2007), The Convergence and Differentiation of Higher Education: A Comparison of Taiwan and Britain, The Development and Governance of Higher Education: Comparative Perspectives Conference. National University of Tainan. 


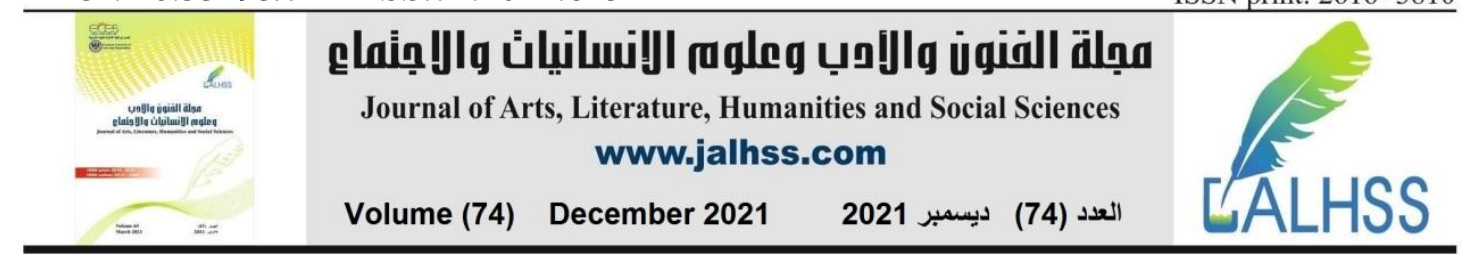

4. Corcoran A., \& Suzanne J., (2004). Duty, Discretion and Conflict: University Governance and the Legal Obligations of University Boards. Australian Universities' Review, 46 (2), 30-37.

5. Dee, J., (2006), Institutional Autonomy and State-level Accountability: Loosely Coupled Governance and the Public Good, In Tierney, W.: Governance and the Public Good, State University of New York Press, Albany: NY.

6. Degerstedt, J.J. (2000). A university for the 21st century. The University of Michigan Press, Ann Arbor.

7. Ehrenberg, R. (2004), Governing Academia, Cornell University Press, Ithaca.

8. Fabric and Alexander,2008, Governance and quality guidelines in Higher Education, OECD.

9. Geuna, A.,\& Muscio A.,(2009), The Governance of University Knowledge Transfer: A Critical Review of the Literature, Minerva: A Review of Science, Learning and Policy, 47 (1), 93-114.

10. Gregory, Holly J. et . Al, 2002, Comparative Study Of Corporate Governance Codes Relevant To The European Union And Its Member States, EASD, European Association Of Securities Dealers.

11. Halawa J. and Taha N. (2012). Governance in Al Quds University. Algerian Institutions Performance Magazine.

12. Henke M.(2007), Can Academic Autonomy Survive in The Knowledge Society? A perspective from Britain, Higher Education Research \& Development, 26( 1), 66- 89.

13. Kim T., (2007), Changing University Governance and Management in the U.K and Elsewhere Under Market Conditions: Issues of Quality Assurance and Accountability, London: Brunei University.

14. Kostyuk, Alexander N., et.al,2007, Corporate Governance, Virtus Interprets, Ukraine.

Lee, Lung S., \& Land, H., (2010), What University Governance Can Taiwan Learn from the United States? Online Submission, Paper presented at the International Presidential Forum, Harbin, China.

15. Salmi, J. (2009), The Challenge of Establishing World-Class Universities, World Bank, Washington, D.C.

16. Shattock, M. (2006). Managing good governance in higher education. Open University Press, Berkshire.

17. Sherif O.,(2007), Laws Governing Higher Education in Egypt, University Governance Conference; A key to Effective Higher Education in Egypt, Back ground paper, Bibliotheca Alexandrina. 


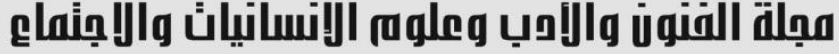 \\ Journal of Arts, Literature, Humanities and Social Sciences www.jalhss.com}

Volume (74) December 2021

العدد (74) ديسمبر 2021

18. Shleifer, Andrei and Vishny, Robert W.,1997, A Survey of Corporate Governance, The Journal Of Finance . Vol. LII, No. 2.

19. Tilley, A.G. (1998). University governance and policy-making. Journal of Higher Education Policy and Management, Vol. 20, No.1, pp.5-11.

20. Trakman, L.( 2011) “Modelling University Governance." University of New South Wales.

21. McKenzie, Phillip.(2003). EDUCATION POLICY ANALYSIS 2003.OECD.ORG

22. Galaz-Fontes, J.F.(2012). Faculty and Institutional Governance in American Higher Education.

23. John V. Lombardi and Diane D. Craig and Elizabeth D. Capaldi Denise S. Gater. ( 2002 ) . University Organization, Governance, and Competitiveness. The Top American Research Universities An Annual Report from The Lombardi Program on Measuring University Performance 